\title{
Pemaksaan Perkawinan Berkedok Tradisi Budaya: Bagaimana Implementasi CEDAW terhadap Hukum Nasional dalam Melindungi Hak-Hak Perempuan dalam Perkawinan?
}

\author{
Junita Fanny Nainggolan; Ramlan; Rahayu R. Harahap \\ Fakultas Hukum Universitas Jambi \\ *Corresponding author: ju2fanny@gmail.com
}

$\begin{array}{ll}\text { Submission } & : 17 \text { November } 2021 \\ \text { Revision } & : 14 \text { Februari } 2022 \\ \text { Publication } & : 18 \text { Februari } 2022\end{array}$

\begin{abstract}
.
This article discusses the implementation of CEDAW into national law to protect women's rights in marriage. Even though the convention has been ratified for decades, in social life, women are still often discriminated against. One form of discrimination in Indonesia is still a patriarchal culture that develops in society. The patriarchy that dominates the culture of society creates sexism and gender inequality that affects many aspects of human activity, one of which is the issue of marriage. In Indonesia, there are still many marriages that occur Indonesia because of forced marriages. Moreover, it is carried out under the guise of a tradition that has experienced a shift in cultural values. The choice to marry and with whom is closely related to selfdetermination which has been recognized in the CEDAW Convention. The results of this study indicate that in the CEDAW Convention, everyone has the same right to marry, regardless of the gender and gender of the person. However, in its implementation into national law, its implementation is still discriminatory and not yet integrated.
\end{abstract}

Keywords: CEDAW; forced marriage; women's rights 


\begin{abstract}
Abstrak
Artikel ini membahas mengenai implementasi CEDAW kedalam hukum nasional untuk melindungi hak-hak perempuan dalam perkawinan. Meski sudah puluhan tahun konvensi diratifikasi, namun dalam kehidupan bermasyarakat, perempuan masih sering didiskriminasi. Salah satu bentuk diskriminasi di Indonesia masih berupa budaya patriarki yang berkembang di masyarakat. Patriarki yang mendominasi budaya masyarakat menciptakan seksisme dan ketidaksetaraan gender yang mempengaruhi banyak aspek aktivitas manusia, salah satunya adalah masalah pernikahan. Di Indonesia, masih banyak perkawinan yang terjadi di Indonesia karena kawin paksa. Apalagi dilakukan dengan kedok tradisi yang telah mengalami pergeseran nilai budaya. Pilihan untuk menikah dan dengan siapa berkaitan erat dengan penentuan nasib sendiri yang telah diakui dalam Konvensi CEDAW. Hasil penelitian ini menunjukan bahwa di dalam Konvensi CEDAW, setiap orang memiliki hak yang sama untuk menikah, terlepas dari gender dan jenis kelamin orang tersebut. Namun, di dalam pengimplementasiannya ke dalam hukum nasional, pelaksanaannya masih bersifat diskiminatif dan belum terintegrasi.
\end{abstract}

Kata Kunci: CEDAW; hak perempuan; pemaksaan perkawinan

\title{
A. Pendahuluan
}

Artikel ini membahas mengenai hak perempuan untuk mendapatkan perlindungan dalam kasus pemaksaan perkawinan sesuai pengaturan yang terdapat dalam Convention on the Elimination of All Forms of Discrimination Against Women (CEDAW). Sejak berlakunya Konvensi CEDAW pada tanggal 3 September 1981, sudah ada 189 negara yang meratifikasi perjanjian internasional ini ke hukum negaranya, termasuk Indonesia. Indonesia meratifikasi dan mengesahkan Konvensi CEDAW pada tanggal 24 Juli 1984 menjadi UndangUndang Nomor 7 Tahun 1984 tentang Pengesahan Konvensi 
mengenai Penghapusan Segala Bentuk Diskriminasi terhadap Wanita.

Sebelum tercetusnya CEDAW, tidak ada dokumen secara komprehensif yang membahas hak-hak dasar perempuan dalam politik, kehidupan budaya, ekonomi, sosial, dan keluarga. Hingga akhirnya pada tanggal 18 Desember 1979, PBB mengadopsi Konvensi CEDAW atau yang sering juga disebut sebagai "bill of rights" internasional bagi perempuan. Faktanya, walaupun sudah berpuluh-puluh tahun Konvensi CEDAW disahkan, di dalam kehidupan bermasyarakat, wanita masih sering mendapatkan perlakuan diskriminasi. Diskriminasi ini terjadi di mana saja, termasuk di Indonesia. Secara harfiah, pengertian diskriminasi adalah perlakuan yang kurang baik bagi siapapun berdasarkan jenis kelamin, ras dan sebagainya.

Hal tersebut dianggap sebagai penghambat pencapaian tujuan kesetaraan, pembangunan dan perdamaian. ${ }^{1}$ Istilah diskriminasi telah disepakati dalam Pasal 1 Konvensi CEDAW yang menyatakan bahwa istilah diskriminasi terhadap perempuan tidak boleh berlaku untuk diskriminasi, pengucilan, atau pembatasan apapun yang dibuat atas dasar jenis kelamin dengan akibat atau tujuan untuk mengurangi

${ }^{1}$ Samidha Pokharel. Gender Discrimination: Women Perspectives. Nepalese Journal of Development and Rural Studies. Vol. 5, No. 2. 2008. hal. 84. 
atau menghilangkan pengakuan, penikmatan, atau pelaksanaan hak politik, ekonomi, sosial, budaya. Dikatakan bahwa itu adalah septum bagi perempuan, sipil atau sebaliknya, terlepas dari status perkawinan mereka berdasarkan kesetaraan laki-laki dan perempuan².

Salah satu bentuk diskriminasi di Indonesia masih berupa budaya patriarki yang berkembang di masyarakat. Patriarki sendiri berasal dari kata patriarkat yang berarti peran laki-laki sebagai satu-satunya penguasa, pusat, dan segalanya adalah struktur tata letaknya. Patriarki yang mendominasi budaya masyarakat menciptakan seksisme dan ketidakadilan gender yang mempengaruhi banyak aspek aktivitas manusia. Dapat dikatakan bahwa laki-laki memerankan peran utama dalam masyarakat, sementara perempuan memiliki sedikit pengaruh atau sama sekali tidak memiliki hak di bidang umum masyarakat, termasuk sistem ekonomi, sosial, politik, bahkan termasuk di dalamnya pernikahan ${ }^{3}$.

Berbicara mengenai patriarki, salah satu problematikanya ialah permasalahan pernikahan. Budaya patriarki masih belum bisa dipisahkan dari kehidupan

${ }^{2}$ Louisa Yesami Krisnalita. Perempuan, HAM dan Permasalahannya Indonesia. Binamulia Hukum, Vol. 7. No. 1. 2018. hal. 74.

${ }^{3}$ Ade Irma Sakina dan Dessy Hasanah Siti A. Menyoroti Budaya Patriarki Di Indonesia. Share : Social Work Journal, Vol. 7, No. 1. 2017. hal. 71. 
perempuan sehingga masih banyak perlakuan tidak adil terjadi pada anak dan perempuan di negara ini.

Sejatinya pernikahan merupakan ikatan lahir batin dari pasangan yang ingin membentuk keluarga. Pilihan untuk menikah dan dengan siapa sangat terkait erat dengan penentuan nasib sendiri yang telah diakui dalam beberapa instrumen internasional utama sebagai hak asasi manusia yang fundamental. ${ }^{4}$ Menurut Komnas Perempuan, pemaksaan perkawinan lebih menyasar pada perempuan karena posisi subordinat dalam masyarakat. Penggunaan kekerasan dan/atau paksaan terhadap seseorang untuk melangsungkan perkawinan menjadi unsur pemaksaan perkawinan. Banyak hal yang menjadi faktor terjadinya pemaksaan perkawinan, khususnya di Indonesia. Salah satu contohnya adalah kawin paksa dikarenakan sebuah tradisi adat yang telah mengalami pergeseran makna budaya seperti yang terjadi di Pulau Sumba, Nusa Tenggara Timur.

Menurut data yang dikumpulkan Aprissa Taranau, ketua Badan Pengurus Nasional Persekutuan Perempuan Berpendidikan Teologi di Indonesia (PERUATI) Sumba, setidaknya ada tujuh kasus kawin tangkap sepanjang 2016

${ }^{4}$ Catherine Dauvergne, Jenni Millbank. Forced Marriage as a Harm in Domestic and International Law. Modern Law Review, Vol. 73, No. 1. 2010. hal. 58.

Uti Possidetis: Journal of International Law, Vol. 3, No. 1 (2022) 
hingga Juni 2020.5 Salah satu kasus kawin tangkap oleh masyarakat Sumba, mengandung unsur bullying dan kekerasan terhadap perempuan karena calon pengantin akan diculik terlebih dahulu, kemudian dinikahkan secara paksa oleh laki-laki yang menculiknya. Pemaksaan perkawinan pun tergolong dalam kekerasan berbasis gender. Komnas Perempuan mengatakan kekerasan terhadap perempuan adalah tindakan kekerasan terhadap perempuan yang menyebabkan atau cenderung menimbulkan atau menyebabkan kesengsaraan dan penderitaan fisik, seksual, psikologis baik bagi perempuan dewasa maupun anak perempuan dan remaja.

Persyaratan bahwa pernikahan dilakukan hanya dengan kebebasan dan persetujuan penuh dari kedua belah pihak sebenarnya sudah dicetuskan. Hal itu pertama kali diabadikan dalam Pasal 16 Deklarasi Universal Hak Asasi Manusia (UDHR) 1948 yang berbunyi :

"(1) Men and women of full age, without any limitation due to race, nationality, or religion, have the right to marry and to found a family. They are entitled to equal rights as to marriage, during the marriage, and at its dissolution.

(2) Marriage shall be entered into only with the free and full consent of the intending spouses.

${ }^{5}$ Liza Tambunan. Kawin Tangkap: Kisah perempuan diculik untuk dinikahi di Sumba, menangis sampai tenggorokan kering. 2020. https://www.bbc.com/indonesia/indonesia-53317050. Diakses pada tanggal 2 Februari 2022. 
(3) The family is the natural and fundamental group unit of society and is entitled to protection by society and the State. Men and women of full age, without any limitation due to race, nationality, or religion, have the right to marry and to found a family. They are entitled to equal rights as to marriage, during marriage and at its dissolution; ..."

Lalu, Konvensi CEDAW membahas hak-hak perkawinan secara lebih rinci termasuk kesetaraan status dalam perkawinan sebagai pengakuan atas fakta bahwa secara historis perkawinan telah dilakukan. Hal tersebut tertera pada Pasal 16 ayat (1) Konvensi CEDAW, yakni :

“(1) States Parties shall take all appropriate measures to eliminate discrimination against women in all matters relating to marriage and family relations and in particular shall ensure, on a basis of equality of men and women:

(a) The same right to enter into marriage;

(b) The same right freely to choose a spouse and to enter into marriage only with their free and full consent; ..."

Hal ini memperluas bahasa persetujuan untuk memasukkan hak yang sama atas kebebasan dalam memilih pasangan untuk menikah dan persetujuan dalam pernikahan hanya dari mereka yang menikah. ${ }^{6}$ Lebih lanjut di dalam hukum nasional sendiri, Indonesia telah meratifikasi Konvensi CEDAW pada 24 Juli 1984 melalui Undang-Undang Republik Indonesia Nomor 7 Tahun 1984 tentang Pengesahan Konvensi Mengenai Penghapusan Segala Bentuk Diskriminasi Terhadap

${ }^{6}$ Dauvergne Catherine, Millbank Jenni. Loc. Cit.

Uti Possidetis: Journal of International Law, Vol. 3, No. 1 (2022) 
Perempuan. Dan Indonesia juga memiliki produk hukum mengenai perkawinan yang tertera dalam Undang-Undang Nomor 1 Tahun 1974 tentang Perkawinan.

Apabila hak atas perkawinan seseorang dilanggar, maka hal tersebut melanggar ketentuan Konvensi CEDAW yang tercantum dalam Pasal 16 ayat (1). Pada pasal itu disebutkan bahwa negara-negara peserta wajib membuat peraturan-peraturan yang tepat untuk menghapus diskriminasi terhadap perempuan dalam semua urusan yang berhubungan dengan perkawinan dan hubungan kekeluargaan atas dasar persamaan antara laki-laki dan perempuan, salah satunya ialah kebebasan untuk memilih suami secara bebas dan untuk memasuki jenjang perkawinan hanya dengan persetujuan yang bebas dan sepenuhnya.

Kemudian, di dalam Undang-Undang Nomor 1 Tahun 1974 ditekankan bahwa perkawinan harus berdasarkan persetujuan kedua calon mempelai sebagaimana tertera di dalam Pasal 6 ayat (1). Dalam penjelasan di pasal tersebut pun disebutkan bahwa perkawinan harus disetujui kedua belah pihak yang hendak melangsungkan pernikahan tanpa ada unsur paksaan dari pihak mana pun. Hal ini memiliki maksud agar suami istri dapat membentuk keluarga yang kekal dan bahagia.

Pembahasan ini menjadi hal yang penting untuk dibahas karena terus menjadi polemik di masyarakat. Dalam 
perbuatan kawin paksa, perempuan korban kehilangan hak konstitusionalnya dan juga hak asasinya, yaitu untuk membentuk keluarga dan meneruskan keturunan melalui perkawinan yang sah.

\section{B. Pembahasan}

\section{Perlindungan Hukum terhadap Perempuan dalam Perkawinan Paksa menurut CEDAW}

Di bawah hukum internasional, hukum perkawinan berhubungan erat dengan hak atas keluaga yang dipahami sebagai "unit kelompok masyarakat yang alami dan mendasar serta berhak atas perlindungan oleh masyarakat dan negara" sesuai Pasal 16 ayat (3) Deklarasi Universal Hak Asasi Manusia (UDHR). Kehidupan keluarga diakui sebagai hak fundamental dalam hukum internasional yang dinyatakan dalam instrumen dan konvensi internasional, salah satunya ialah CEDAW 7 .

Di dalam CEDAW telah disebutkan dalam Pasal 16 Konvensi CEDAW bahwa orang memiliki hak yang sama untuk menikah. Di pasal tersebut disebutkan bahwa negara-negara pihak harus mengambil semua tindakan yang tepat untuk menghapus diskriminasi terhadap perempuan dalam segala hal yang berkaitan dengan perkawinan dan hubungan keluarga, dan khususnya harus menjamin atas dasar

7 Rahayu. Kepedulian Hukum Internasional Terhadap Perlindungan Hak Asasi Manusia. in Penghapusan Diskriminasi Terhadap Wanita. Bandung: Penerbit Alumni. 2000. hal. 120.

Uti Possidetis: Journal of International Law, Vol. 3, No. 1 (2022) 
persamaan antara laki-laki dan perempuan. Serta disebutkan bahwa laki-laki dan perempuan memiliki hak yang sama untuk menikah dan bebas memilih pasangan sesuai kehendaknya.

CEDAW sebagai undang-undang hak internasional bagi perempuan memiliki perjanjian pokok yang berkaitan dengan perlindungan dan realisasi hak-hak perempuan di masyarakat serta dalam ranah privat. Ketika suatu negara memutuskan untuk menerima CEDAW, maka mereka setuju untuk mengambil tindakan yang diperlukan untuk mengakhiri diskriminasi terhadap perempuan ${ }^{8}$. Upaya untuk memberantas segala bentuk diskriminasi yang menyerang perempuan telah diatur dalam Konvensi CEDAW. Perjanjian HAM internasional ini telah menjamin hak semua individu. Salah satu haknya ialah hak untuk menikah dengan persetujuan bebas dan penuh dari kedua belah pihak.

Dalam contoh kasus pemaksaan perkawinan yang terjadi di Pulau Sumba yang berkedok sebuah kebudayaan bisa dicermati bahwa konflik praktik budaya dan agama merupakan area kontroversi yang menyebabkan banyak keberatan dalam penegakan hak-hak perempuan. Di dalam perkawinan dalam penegakan HAM tersebut sering terjadi pertentangan karena negara-negara sering angkat tangan atas

8 Emma Tuininga. The Impact of CEDAW on Women's Marital Rights: An Overview of Recent International Legislative Developments. Tesis. Belanda: Universitas Tilburg. 2018. hal. 29. 
masalah tersebut, juga memiliki berbagai alasan untuk menunda pembentukan undang-undang yang berguna untuk menegakkan kesetaaan antara laki-laki dan perempuan ${ }^{9}$.

Salah satu bentuk diskriminasi di Indonesia masih berupa budaya patriarki yang berkembang di masyarakat. Budaya patriarki masih belum bisa dipisahkan dari kehidupan perempuan sehingga masih banyak perlakuan tak adil terjadi pada anak dan perempuan di negara ini. Patriartki sendiri berasal dari kata patriarkat yang berarti peran laki-laki sebagai satu-satunya penguasa, pusat, dan segalanya adalah struktur tata letaknya. Budaya patriarki yang menundukkan perempuan biasa dimulai dari keluarga. Perlakuan ini terjadi di tingkat keluarga dan kemudian meluas ke ranah publik. Laki-laki diberkahi dengan hak-hak istimewa oleh budaya yang menjadikan mereka pusat kekuasaan baik di tingkat keluarga maupun publik, sementara perempuan hanyalah pelengkap $^{10}$.

Menurut Susanto, sejarah diskriminasi terhadap perempuan sudah cukup panjang dan beragam lintas ras, wilayah, dan negara. Sejak awal, patriarki telah membentuk

9 Franz Magnis Suseno, Philip Alston. Hukum Hak Asasi Manusia. Yogyakarta: Pusat Studi Hak Asasi Manusia Universitas Islam Indonesia (PUSHAM UII). 2008. hal. 150.

10 Ema Tusianti, Dyah Prihatinningsih \& Dina Rahmawati. Pembangunan Manusia Berbasis Gender 2016. Jakarta: BPS and KPPPA. 2016. hal. 9.

Uti Possidetis: Journal of International Law, Vol. 3, No. 1 (2022) 
peradaban di mana laki-laki dianggap superior dalam segala hal. Ini datang dalam bentuk streotip, marginalisasi, subordinasi, tindakan kekerasan, dan beban kerja11. Idenya adalah bahwa kondisi sosial yang mendorong perilaku kekerasan seringkali mencerminkan ketidaksetaraan sosial dan ekonomi di antara masyarakat atau mencerminkan ketidaksetaraan sosial dan ekonomi. Pada Violence Against Women, Hosking menyatakan bahwa berbagai studi tentang seksisme telah menemukan hubungan antara tingkat kekerasan terhadap perempuan. Jacobson telah mengidentifikasi beberapa faktor sosial yang dapat menciptakan kondisi kekerasan termasuk terhadap kekerasan perempuan $^{12}$ :

1. Sikap permisif masyarakat;

2. Melonggarkan kontrol laki-laki atas pengambilan keputusan dan pembatasan kebebasan perempuan;

3. Menyusun peran laki-laki dan perempuan dalam status sosial dan masyarakat yang kaku;

4. Hubungan antar sesama yang merendahkan perempuan;

5. Kumuhnya lingkungan dan kepadatan penduduk;

6. Keterpaparan pada kekerasan.

Konvensi CEDAW menempatkan hak-hak perempuan dalam hal gender di jantung, pusat teori dan praktik HAM.

\section{Ibid.}

12 Riyadi Aprilia Ira Pratiwi, et. al. Statistik Gender TematikMengakhiri Kekerasan Terhadap Perempuan dan Anak di Indonesia. Jakarta: Kementerian Pemberdayaan Perempuan dan Perlindungan Anak. 2017. hal. 20. 
Dasar dari Konvensi CEDAW adalah prinsip kesetaraan gender. Asas persamaan antara laki-laki dan perempuan sebenarnya ada tidak hanya dalam pengertian persamaan yang secara formal ditentukan dalam hukum, tetapi juga secara de facto dan substantif, yaitu persamaan yang hakiki. Kelahiran CEDAW tidak mendikotomikan ranah publik dan privat. Di sisi lain, CEDAW memastikan bahwa penerapan sistem HAM yang holistik harus secara bersamaan mencakup hak-hak di dalam semua kehidupan manusia13.

Budaya, sama halnya dengan hukum, adalah konsep yang kompleks. Ini mencakup nilai-nilai, aspirasi, bahasa, dan ideologi masyarakat. Sebagai sebuah konsep, budaya secara historis dan sosiologis spesifik. Budaya membawa serta makna khusus yang membutuhkan apresiasi khusus. Setiap penilaian serius terhadap tatanan hukum internasional maupun nasional harus mempertimbangkan pluratitas budaya di dunia. Hukum dan budaya menyatu dalam berbagai bidang seperti dalam hak asasi manusia individu dan penentuan nasib sendiri, mendefinisikan otonomi budaya dan dalam melindungi warisan budaya ${ }^{14}$.

${ }^{13}$ Lusiana Margareth Tijow. Perlindungan Hukum Bagi Perempuan Korban Janji Kawin. Malang: Inteligensia Media. 2017. hal. 144.

14 Christopher C Joyner, John C Dettling. Bridging the Cultural Chasm: Cultural Relativism and the Future of International

Uti Possidetis: Journal of International Law, Vol. 3, No. 1 (2022) 
Dalam kasus yang terjadi, pergeseran makna kebudayaan yang menghambat keberlangsungan untuk mencapai hasil dari peraturan yang ditetapkan. Di dalam Pasal 5 Konvensi CEDAW telah dijelaskan bahwa negara-negara harus mengambil semua langkah yang tepat untuk memperbaiki pola perilaku sosial dan budaya pria dan wanita. Diharapkan juga prasangka dan adat istiadat, dan semua praktik lain yang didasarkan pada inferioritas atau superioritas gender, atau stereotip pria dan wanita dihilangkan.

Berdasarkan isi Pasal 5 Konvensi CEDAW, diharapkan negara menjalani ketentuan tersebut dan terciptanya kesadaran publik tentang praktik budaya yang berbahaya. Pemerintah diharapkan juga mengadopsi undang-undang yang tepat untuk menanggani praktik semacam kawin paksa yang ada di Pulau Sumba serta memberikan dukungan kepada perempuan yang menjadi korban praktik budaya berbahaya tersebut. Sebagaimana prinsip yang dianut Konvensi CEDAW, yaitu prinsip non-diskriminasi dan prinsip kesetaraan adalah dua pilar HAM yang diakui di hampir semua instrumen HAM. Tidak ada definisi yang diterima secara umum dari istilah "kesetaraan", umumnya dapat diterima bahwa kesetaraan sama saja dengan non-diskriminasi. Oleh karena itu tindakan

Law. California Western International Law Journal, Vol. 20, No. 2. 2015. hal. 276. 
diskiminasi akan mengakibatkan pelanggaran hak atas kesetaraan ${ }^{15}$.

\section{Implementasi CEDAW di Undang-Undang Nomor 1 Tahun 1974 tentang Perkawinan}

Di dalam Pasal 1 Undang-undang Republik Indonesia Nomor 1 Tahun 1974 disebutkan bahwa: "Perkawinan ialah ikatan lahir batin antara seorang pria dengan seorang wanita sebagai suami istri dengan tujuan membentuk keluarga (rumah tangga) yang bahagia dan kekal berdasarkan Ketuhanan Yang Maha Esa". Berdasarkan pengertian tersebut dapat disimpulkan bahwa perkawinan adalah bersatunya dua orang yang secara sah atau resmi diakui sebagai pasangan dalam hubungan kekerabatan antara laki-laki dan perempuan. Beda negara beda pula ketentuan untuk menentukan sahnya perkawinan seseorang. Di Indonesia, perkawinan ditentukan dalam Undang-Undang Nomor 1 Tahun 1974 yang digunakan sebagai pembinaan hukum nasional yang berlaku bagi semua warga negara. Sehingga tiap pelaksaan perkawinan yang terjadi di Indonesia harus didasarkan dengan perundangundangan tersebut.

${ }^{15}$ Ebenezer Durojaye, Yinka Owoeye. Equally Unequal or Unequally Equal: Adopting a Substantive Equality Approach to Gender Discrimination in Nigeria. International Journal of Discrimination and the Law, Vol. 17, No. 2. 2017. hal. 73.

Uti Possidetis: Journal of International Law, Vol. 3, No. 1 (2022) 
Pernikahan termasuk sebagai hak fundamental warga negara telah dijamin dalam Perubahan Kedua Undang-Undang Dasar Negara Republik Indonesia Tahun 1945. Pasal 28B ayat (1) telah dijabarkan bahwa setiap orang berhak membentuk sebuah keluarga dan garis keturunan melalui perkawinan yang sah. Lalu, di Pasal 27 ayat (1) Undang-Undang 1945 juga dijelaskan mengenai pengakuan atas asas persamaan bagi semua warga negara tanpa terkecuali. Asas persamaan ini menghilangkan diskriminasi yang oleh karena itu setiap warga negara memiliki hak yang sama di mata hukum tanpa membedakan agama, suku, kedudukan, golongan, dan jenis kelamin warga negaranya.

Berkenaan dengan pemaksaan perkawinan, Undangundang Nomor 1 Tahun 1974 tentang Perkawinan tidak menjelaskan secara terang mengenai pengertian pemaksaan perkawinan di dalam hukum nasional Indonesia. Namun, mengingat konsep kesukarelaan atau kesepakatan kedua mempelai menurut Undang-Undang Nomor 1 Tahun 1974 dapat diterangkan bahwa yang dimaksud pemaksaan pekawinan ialah perkawinan karena adanya unsur paksaan dari orang lain ${ }^{16}$. Pemaksaan perkawinan merupakan salah satu bentuk kekerasan seksual terhadap wanita seperti yang

16 Sumadi Anis Anjalis. Forced Marriage Practices in Village Cibeureum Ciamis District (Study Analysis Of Law No. 23 Of 2004 Concerning Elimination Of Household Violence). Al-Afkar, Vol. 2, No. 1. 2019. hal. 4 . 
diidentifikasi oleh Komnas Perempuan. Kekerasan seksual adalah bentuk konkrit atau dominasi kekuasaan dengan kekerasan. Kekerasan seksual adalah suatu bentuk pengendalian seksual di mana satu pihak berusaha untuk menggunakan kekuasaan dan otoritas dalam berbagai bentuk, mereka mengendalikan orang lain secara seksual, bahkan membuat korbannya setuju tanpa menyadarinya.

Dalam kaitan ini, kawin paksa merupakan fenomena sosial yang sudah ada sejak lama dan merupakan fenomena "lumrah" di masyarakat. Praktik kawin paksa sebenarnya memiliki beberapa jenis motifnya. Salah satunya adalah pemaksaan perkawinan oleh seorang individu pada lawan jenisnya. Biasa hal ini terjadi ketika pelaku ingin menikahi korbannya tetapi korban menolak untuk dinikahan sehingga terjadilah pemaksaan ${ }^{17}$. Pada pertengahan tahun 2020 pada bulan Juni perhatian publik tertuju pada praktik "kawin tangkap" di kawasan Sumba, Nusa Tenggara Timur. Ada rekaman yang menunjukkan seorang wanita dibawa secara paksa ke tempat yang diatur oleh pria. Proses penangkapan bisa dilakukan di mana saja, termasuk di tempat-tempat umum seperti pasar, jalan, bahkan tempat tinggal korban. Meski wanita itu menolak dan mencoba membela diri, jarang

17 Anak Agung Istri Ari Atu Dewi, Deybi Santi Wuri. Pemaksaan Perkawinan Sebagai Faktor Terjadinya Kekerasan dalam Rumah Tangga Ditinjau dari Perspektif Hukum Pidana Indonesia. Kertha Wicara : Journal Ilmu Hukum, Vol.9, No. 5. 2020. hal. 5. 
ada orang yang membantu kecuali orang tesebut salah satu dari anggota keluarga korban. Dengan demikian, setelah penangkapan keluarga korban akan diberitahu tentang penangkapan tersebut sekaligus untuk dipinang. Bila pihak keluarga korban tidak berhasil menyelamatkan, maka keluarga korban sering kali terdesak menerima perkawinan tersebut. Hal ini dapat menimpa korban yang berasal dari latar belakang pendidikan apapun serta usia korban bisa anak-anak, remaja maupun wanita dewasa. ${ }^{18}$

Pemaksaan perkawinan sering digambarkan sebagai permasalahan yang mempengaruhi perempuan dan anak. Namun kenyataannya pemaksaan perkawinan mempengaruhi berbagai komunitas tanpa memandang latar belakang orang tersebut. Karena tidak ada satu pun negara di dunia ini yang mendukung ataupun menganjurkan praktik kawin paksa sehingga praktik yang diskriminatif ini harus dihapuskan. Pemaksaan perkawinan pada orang dewasa bahkan lebih kompleks. Banyak yang beranggapan bahwa hal tersebut adalah hal yang lumrah mengingat umur orang dewasa tersebut sudah mencapai usia yang diperbolehkan untuk menikah oleh hukum positif. Apalagi jika pemaksaan

${ }^{18}$ Siaran Pers Komnas Perempuan atas Praktik Kawin Tangkap di Sumba (24 Juni 2020). https://komnasperempuan.go.id /siaran-pers-detail/siaran-pers-komnas-perempuan-atas-praktikkawin-tangkap-di-sumba-24-juni-2020 diakses pada 14 September 2021.

Uti Possidetis: Journal of International Law, Vol. 3, No. 1 (2022) 
perkawinan tersebut berkedok perjodohan yang menyangkutpautkan kebudayaan.

Faktor yang mempengaruhi terjadinya pemaksaan perkawinan ialah budaya dan ideologi patriarti yang tersosialisasi di dalam masyarakat yang disebabkan pembenaran untuk berbagai aspek kehidupan. Aspek tersebut bisa dilihat dari segi kehidupan beragama, berkeyakinan, dan bernegara. Sebab, secara historis banyak sekali perempuan yang mempunyai posisi penting di masyarakat dan negara tetapi perempuan tersebut tidak selalu mendapatkan apresiasi atas peran dan posisinya. ${ }^{19}$ Isu gender memang telah ada di dalam diri manusia sejak pertama kali muncul di muka bumi. Namun, karena limitnya perkembangan ilmu pengetahuan dan teknologi, pada awalnya isu gender diabaikan dan tidak dipersoalkan oleh masyarakat. Hal ini disebabkan tumbuhnya nilai-nilai budaya yang berkaitan dengan peran atau pembagian kerja, tanggungjawab dan standar citra laki-laki dan perempuan yang kemudian dianggap sebagai sesuatu yang wajar. ${ }^{20}$

19 Lusia Palulungan, M. Ghufran H. Kordi K. \& Muhammad Taufan Ramli. Perempuan, Masyarakat Patriarki \& Kesetaraan Gender. Makassar: Yayasan Bursa Pengetahuan Kawasan Timur Indonesia (BaKTI). 2020. hal. 4.

20 Mentari Berliana Kemala Dewi, Ridwan Arifin. Emancipation and Legal Justice; Portrait of Women's Legal Protection in Indonesia. Jurnal Cita Hukum, Vol. 7, No. 1. 2019. hal. 104. 
Situasi kawin paksa ini sudah seharusnya dicermai dengan seksama oleh negara. Sebab korban dari pemaksaan perkawinan tak berdaya untuk menghadapi situasi pelik yang dihadapinya sehingga mereka terpaksa menerima pernikahan tersebut. Karena tak jarang jika pihak wanita yang hendak dinikahi dalam kasus yang terjadi di Pulau Sumba apabila menolak lamaran tersebut maka ia dianggap telah mencoreng nama baik keluarganya. Lalu korban pemaksaan perkawinan jarang sekali melaporkan kejadian ini kepada pihak berwajib.

Diskriminasi terhadap perempuan membuat keterpurukan bagi para penyitasnya. Penghapusan diskiminasi menjadi suatu keperluan kehidupan dan keadilan untuk perempuan dan laki-laki dapat dicapai tanpa adanya diskiminasi. Hukum hak asasi internasional telah menjamin bahwa tidak boleh ada suatu negara yang sengaja mengabaikan hak-hak dan kebebasan-kebebasan tersebut. Sebaliknya, negara diminta menjalani kewajibannya agar dapat melindungi secara tangkas serta menjamin bahwa terjelma hak-hak warga negara serta kebebasannya. ${ }^{21}$

Indonesia pun melakukan perubahan drastis guna perbaikan bidang hukum dengan adanya undang-undang yang mengatur tentang perlindungan HAM seperti Undang-Undang Nomor 39 Tahun 1999 menjadikan warga negara Indonesia lebih terlindungi hak-hak asasinya. Hal ini senada dengan

21 Philip Alston dan Franz Magnis-Suseno. Op.Cit. hal. 40. 
prinsip perlindungan hukum bahwa setiap perlindungan terhadap HAM yang telah direnggut oleh orang lain harus diberikan pengayoman oleh aparat penegak hukum agar setiap korban merasa aman secara mental dan fisik dari individu lain yang melanggar HAM mereka. Dengan adanya undang-undang tersebut, semua peraturan perundang-undangan tunduk pada prinsip-prinsip perlindungan HAM yang diatur UndangUndang Nomor 39 Tahun 1999. Di antaranya adalah penghapusan diskriminasi yang didasari oleh agama, suku, ras, etnik, kelompok, golongan, sosial, ekonomi, jenis kelamin, bahasa, serta keyakinan berpolitik. Pelanggaran nondiskriminasi di atur dalam Pasal 3 ayat (3): "Setiap orang berhak atas perlindungan hak asasi manusia dan kebebasan dasar manusia, tanpa diskriminasi". ${ }^{22}$

Terkait dengan perkawinan, pada Pasal 10 ayat (2) Undang-Undang Nomor 39 Tahun 1999 tentang Hak Asasi Manusia menyatakan bahwa "perkawinan yang sah hanya dapat berlangsung atas kehendak bebas calon suami dan calon istri yang bersangkutan, sesuai dengan ketentuan peraturan perundang-undangan." Hal ini telah berikatan dengan syarat perkawinan yang ada di dalam Pasal 6 ayat (1) UndangUndang Nomor 1 Tahun 1974 yang disebutkan bahwa

22 Dede Kania. Hak Asasi Perempuan dalam Peraturan Perundang-Undangan di Indonesia (The Rights of Women in Indonesian Laws and Regulations). Jurnal Konstitusi, Vol. 12, No. 4. 2015. hal. 719.

Uti Possidetis: Journal of International Law, Vol. 3, No. 1 (2022) 
perkawinan patut didasarkan atas persetujuan kedua calon pengantin.

Hukum dapat dilihat dalam wujudnya melalui aturanaturan yang dirumuskan secara eksplisit. Dalam suatu kaidah atau pengaturan hukum terhadap perbuatan-perbuatan yang harus dilaksanakan, dan itu tidak lain adalah penegakan hukum. Hukum harus ditegakkan, oleh karena itu tidak heran bila dikatakan jika undang-undang ini tidak ditegakkan, maka tidak dapat lagi disebut undang-undang. Penegakan hukum selalu melibatkan orang dan tindakannya. Suatu hukum tidak dapat ditegakkan dengan sendiri, artinya tidak dapat memenuhi janji dan kehendak yang terkandung dalam ketentuannya ${ }^{23}$. Misalnya dalam kasus ini, korban yang dijamin hak asasinya harus dilindungi serta hukuman pun dijatuhkan kepada orang yang merenggut hak asasi korban pemaksaan perkawinan tersebut.

HAM harus ada di tiap negara, termasuk konteks budaya tertentu di negara-negara tersebut. Karena semua budaya memiliki hak yang sama untuk hidup dan bermartabat, yang harus dihormati, penerapan HAM harus mempertimbangkan karakteristik, perbedaan sejarah, budaya dan agama masing-masing negara. Di Indonesia, penerapan dan pelaksanaan HAM harus sejalan dengan nilai-nilai dan

23 Ishaq. Dasar-dasar Ilmu Hukum. Jakarta: Sinar Grafika. 2008. hal. 305. 
budaya yang berlaku di Indonesia. Penghormatan Negara Indonesia terhadap berbagai konvensi dan instrumen hukum internasional, termasuk HAM, harus didasarkan pada sejarah, budaya, falsafah, dan konstitusi Republik Indonesia ${ }^{24}$.

Aturan sebagai hukum merupakan pengatur hidup dalam interaksi sosial yang sebenarnya mencerminkan citacita atau sistem nilai yang berlaku umum dalam masyarakat. Jika ada pelanggaran oleh anggota masyarakat, kepentingan yang terkena harus diganti atau diperbaiki. Aturan harus dipertahankan dan pelanggar harus dikenakan sanksi hukuman yang dijatuhkan kepada mereka oleh badan-badan kekuasaan publik. Maka dari itu, praktik kebudayaan yang melenceng harus dibinasakan sebab tidak mencerminkan nilai kebudayaan yang sesungguhnya, dan juga supaya hak-hak perempuan di Indonesia yang menjadi korban pemaksaan perkawinan berbasis budaya dapat dipulihkan.

Tujuan hukum adalah untuk melindungi kepentingan tersebut. Namun, justru karena kepentingan tersebut saling bertentangan, maka hukum tidak mungkin memberikan perlindungan penuh bagi suatu kepentingan dan mengesampingkan yang lain. Jadi perlindungan kepentingankepentingan ini harus menemukan jalan perantara dan dengan

24 Belardo Prasetya Mega Jaya, Muhammad Rusli Arafat. Universalism Vs. Cultural Relativism dan Implementasinya dalam Hak Kebebasan Beragama di Indonesia. Pena Justisia: Media Komunikasi dan Kajian Hukum, Vol. 17, No. 1. 2018. hal. 64. 
demikian mencoba mencapai kompromi. Hukum menemukan cara untuk menyelesaikan masalah. Artinya, kedua jenis kepentingan yang saling bertentangan dipertimbangkan dengan cermat dan seimbang 25 .

Sayangnya, meskipun undang-undang telah menunjukan bahwa setiap orang memiliki kebebasan terutama dalam masalah perkawinan, pemberlakuannya masih diskiminatif dan belum terintegrasi. Dibutuhkan keseriusan lebih dari negara untuk menerapkan prinsipprinsip utama CEDAW, yakni prinsip persamaan substantif, prinsip non diskriminasi, dan prinsip keajiban negara. Serta, negara harus menjadikan CEDAW sebagai landasan hukum setiap pembuatan kebijakan yang dapat memberikan rasa aman bagi para wanita.

\section{Penutup}

Berdasarkan analisis dan pembahasan di atas, dapat disimpulkan ada beberapa faktor yang dapat diidentifikasi terkait implementasi Konvensi CEDAW dalam perlindungan hak perempuan dalam pemaksaan perkawinan. Upaya untuk mengakhiri diskriminasi pada perempuan dalam pemaksaan perkawinan jelas diatur dalam Konvensi CEDAW. Setiap orang memiliki hak yang sama untuk menikah, terlepas dari gender dan jenis kelamin orang tersebut. Kawin paksa dengan kedok

25 Ifrani. Pengantar Ilmu Hukum. Bandung: Nusa Media. 2020. hal. 13. 
budaya dapat dipahami sebagai bentrok praktik yang mengatasnamakan budaya. Hal tersebut merupakan area kontroversi luas yang mendorong banyak reservasi dalam penegakan hak-hak perempuan. Oleh karena itu, diharapkan negara mengambil langkah-langkah tepat termasuk menciptakan kesadaran masyarakat tentang praktik budaya yang merugikan sesuai yang dijelaskan dalam Konvensi CEDAW.

Selain itu, dalam pengimplementasian CEDAW di Indonesiameskipun undang-undang telah menunjukan bahwa setiap orang memiliki kebebasan terutama dalam hal perkawinan, pelaksanaannya masih bersifat diskiminatif dan belum terintegrasi. Masih terjadi diskriminasi serta kekerasan berbasis gender terhadap para wanita sehingga dibutuhkan keseriusan dari negara untuk menerapkan prinsip-prinsip pokok CEDAW, yaitu prinsip kesetaraan substantif, nondiskiminasi, dan kewajiban negara. Dan negara harus lebih serius dalam menegakkan hukum positif yang menegakkan hak-hak perempuan. Dalam hal ini, perempuan memiliki hak untuk menikah yang merupakan hak fundamentalnya.

\section{Referensi}

Anjalis, Sumadi Anis. Forced Marriage Practices in Village Cibeureum Ciamis District (Study Analysis of Law No. 23 Of 2004 Concerning Elimination of Household Violence). Al-Afkar, Vol. 2, No. 1. 2019. 
Convention on Elimination of All Forms of Discrimination Againts Women (CEDAW).

Dauvergne, Catherine, Jenni Millbank. Forced Marriage as a Harm in Domestic and International Law. Modern Law Review, Vol. 73, No. 1. 2010.

Dewi, Anak Agung Istri Ari Atu, Deybi Santi Wuri. Pemaksaan Perkawinan Sebagai Faktor Terjadinya Kekerasan dalam Rumah Tangga Ditinjau dari Perspektif Hukum Pidana Indonesia. Kertha Wicara : Journal Ilmu Hukum, Vol.9, No. 5. 2020.

Dewi, Mentari Berliana Kemala, Ridwan Arifin. Emancipation and Legal Justice; Portrait of Women's Legal Protection In Indonesia. Jurnal Cita Hukum, Vol. 7, No. 1. 2019.

Durojaye, Ebenezer, Yinka Owoeye. Equally Unequal or Unequally Equal: Adopting a Substantive Equality approach to gender discrimination in Nigeria. International Journal of Discrimination and the Law, Vol. 17, No. 2. 2017.

Ifrani. Pengantar Ilmu Hukum. Bandung: Nusa Media. 2020.

Indonesia. Undang-Undang Nomor 1 Tahun 1974 Tentang Perkawinan. Lembaran Negara Tahun 1974 Nomor 1. Tambahan Lembaran Negara Nomor 3019. , Undang-Undang Nomor 39 Tahun 1999 Tentang Hak Asasi. Lembaran Negara Tahun 1999 Nomor 165. Tambahan Lembaran Negara Nomor 3886. , Undang-Undang Republik Indonesia Nomor 7 Tahun 1984 Tentang Pengesahan Konvensi Mengenai Penghapusan Segala Bentuk Diskiriminasi terhadap 
Wanita. Lembaran Negara Tahun 1984 Nomor 29. Tambahan Lembaran Negara Nomor 3277.

Indonesia Vows to End Practice of Bride Kidnapping. https://www.bbc.com/news/world-asia-53418099 diakses pada tanggal 11 Juni 2021.

Ishaq. Dasar-dasar Ilmu Hukum. Jakarta: Sinar Grafika, 2008.

Jaya, Belardo Prasetya Mega, Muhammad Rusli Arafat. Universalism Vs. Cultural Relativism dan Implementasinya dalam Hak Kebebasan Beragama Di Indonesia. Pena Justisia: Media Komunikasi dan Kajian Hukum, Vol. 17, No. 1. 2018.

Joyner, Christopher C, John C Dettling. Bridging the Cultural Chasm: Cultural Relativism and the Future of International Law. California Western International Law Journal, Vol. 20, No. 2. 2015.

Kania, Dede Kania. Hak Asasi Perempuan dalam Peraturan Perundang-Undangan di Indonesia (The Rights of Women in Indonesian Laws and Regulations). Jurnal Konstitusi, Vol. 12, No. 4. 2015.

Krisnalita, Louisa Yesami. Perempuan, HAM dan Permasalahannya di Indonesia. Binamulia Hukum, Vol. 7. No. 1. 2018.

Palulungan, Lusia, et.al. Perempuan, Masyarakat Patriarki \& Kesetaraan Gender. Makassar: Yayasan Bursa Pengetahuan Kawasan Timur Indonesia (BaKTI). 2020.

Pokharel, Samidha. Gender Discrimination: Women Perspectives. Nepalese Journal of Development and Rural Studies, Vol. 5, No. 2. 2008. 
Pratiwi, Riyadi Aprilia Ira et. al. Statistik Gender TematikMengakhiri Kekerasan Terhadap Perempuan dan Anak di Indonesia. Jakarta: Kementerian Pemberdayaan Perempuan dan Perlindungan Anak. 2017.

Rahayu, Kepedulian Hukum Internasional Terhadap Perlindungan Hak Asasi Manusia. in Penghapusan Diskriminasi Terhadap Wanita. Bandung: Penerbit Alumni. 2000.

Sakina, Ade Irma, Dessy Hasanah Siti A. Menyoroti Budaya Patriarki Di Indonesia. Share : Social Work Journal, Vol. 7, No. 1. 2017.

Siaran Pers Komnas Perempuan atas Praktik Kawin Tangkap di Sumba (24 Juni 2020). https://komnasperempuan.go.id/siaran-persdetail/siaran-pers-komnas-perempuan-atas-praktikkawin-tangkap-di-sumba-24-juni-2020 diakses pada 14 September 2021.

Suseno, Franz Magnis, Philip Alston. Hukum Hak Asasi Manusia. Yogyakarta: Pusat Studi Hak Asasi Manusia Universitas Islam Indonesia (PUSHAM UII). 2008.

Tijow, Lusiana Margareth. Perlindungan Hukum Bagi Perempuan Korban Janji Kawin. Malang: Inteligensia Media. 2017.

Tuininga, Emma. The Impact of CEDAW on Women's Marital Rights: An Overview of Recent International Legislative Developments. Tesis. Belanda: Universitas Tilburg. 2018. hal. 29. 